\title{
ANALISIS PENGELOLAAN RANTAI PASOK TEPUNG KELAPA PADA PT. XYZ DI SULAWESI UTARA
}

\author{
Chintya Stefanny Anis \\ Agnes E. Loho \\ Grace A. J. Rumagit
}

\begin{abstract}
The purpose of this study are: (1) Identify the supply chain model of coconut desiccated at PT. XYZ and (2) to analyze the supply chain management of desiccated coconut at PT. XYZ. The research was conducted over 2 months ie from September to November 2016 and is located in PT. XYZ (pseudonym), in North Sulawesi. The data used in this research are primary and secondary data. The primary data obtained through field observation and direct interviews. Interviews were conducted with the company related logistics company to find a picture of the supply chain and supply chain management is done by the company. In addition, the researchers also conducted interviews with coconut farmers and collectors to determine the condition of the current coconut price as well as the flow of raw material coconuts from the famers to supplier. Secondary data were obtained from the relevant literature, as well as documents and reports that are owned by companies and agencies. This study focuses on the management of the flow of material and information flow of the supply chain of coconut flour at PT. XYZ. The results of observations and interviews were analyzed with descriptive qualitative analysis methods. The results showed that (1) Members of coconut flour supply chain at. XYZ, namely (a) the raw material supplier of coconut spread in some areas, (b) PT. XYZ for purchasing, sales, shipping and production, (c) Expediting Services to send products from Bitung harbor, next to the port of Tanjung Priok to be exported to the country of destination, $(d)$ The customer, in this case the food companies that require raw materials coconut flour to be produced into chocolate bars, cookies, dessert, and so forth. (2) (a) Selection of supplier PT. XYZ is good enough, because every supplier who will supply the raw material to go through the interview stage, made a deal with the company and agree to the terms proposed by the company. PT. XYZ also maintain good relations with its suppliers with visits annually; $(b)$ the flow of material and information flow is managed by PT. XYZ is good enough. Any information purchasing, sales, shipping and finance centered PT.XYZ headquarters is located in Manado and PT. XYZ manage information about the quantity of raw materials available in the warehouse and general condition of the plant.
\end{abstract}

Keywords: supply chain model, coconut flour, North Sulawesi

\section{ABSTRAK}

Tujuan dari penelitian ini adalah: (1) Mengidentifikasi model rantai pasok tepung kelapa pada PT. XYZ dan (2) Menganalisis pengelolaan rantai pasokan tepung kelapa pada PT. XYZ. Penelitian ini dilaksanakan selama 2 bulan yaitu dari bulan September sampai bulan November 2016 dan berlokasi di PT. XYZ (Nama samaran), di Sulawesi Utara. Data yang digunakan dalam penelitan ini adalah data primer dan sekunder. Data primer didapat melalui pengamatan di lapangan serta wawancara secara langsung. Wawancara dilakukan dengan pihak perusahaan terkait logistik perusahaan untuk mengetahui gambaran rantai pasok serta pengelolaan rantai pasok yang dilakukan oleh perusahaan. Selain itu, peneliti juga melakukan wawancara dengan petani kelapa serta pengumpul untuk mengetahui kondisi harga kelapa terkini serta alur bahan baku kelapa dari petani ke supplier. Data sekunder diperoleh dari literatur yang relevan, serta dokumen dan laporan yang dimiliki oleh perusahaan dan instansi terkait. Penelitian ini berfokus pada pengelolaan aliran material serta aliran informasi dari rantai pasok tepung kelapa pada PT. XYZ. Hasil dari observasi dan wawancara dianalisis dengan metode analisis kualitatif deskriptif. Hasil penelitian menunjukkan bahwa (1) Anggota rantai pasok tepung kelapa pada PT. XYZ, yaitu (a) supplier bahan baku kelapa yang tersebar di beberapa daerah, (b) PT. XYZ untuk bagian pembelian, penjualan, pengiriman dan produksi, (c) Jasa Ekspedisi untuk mengirim produk dari pelabuhan Bitung, selanjutnya ke pelabuhan Tanjung Priuk untuk diekspor ke Negara tujuan, (d) Pelanggan, dalam hal ini perusahaan makanan yang membutuhkan bahan baku tepung kelapa untuk diproduksi menjadi cokelat batang, kue, dessert dan lain sebagainya. (2) (a) Pemilihan supplier pada PT. XYZ sudah cukup baik, karena setiap supplier yang akan memasok bahan baku harus melalui tahap wawancara, membuat kesepakatan dengan pihak perusahaan dan menyetujui persyaratan yang diajukan oleh perusahaan. PT. XYZ juga menjaga relasi yang baik dengan para suppliernya dengan mengadakan kunjungan setiap tahunnya. (b) Aliran material dan aliran informasi yang dikelola oleh PT. XYZ cukup baik. Setiap informasi pembelian, penjualan, pengiriman dan keuangan berpusat di Kantor pusat PT.XYZ yang berada di Manado dan pabrik PT. XYZ mengelola informasi tentang kuantitas bahan baku yang tersedia di gudang serta kondisi umum pabrik.

Kata kunci: model rantai pasok, tepung kelapa, Sulawesi Utara 


\section{PENDAHULUAN}

Kelapa merupakan tanaman perkebuan yang cukup besar kontribusinya terhadap perekonomian Indonesia. Perkebunan kelapa memiliki luasan kedua terbesar di Indonesia setelah perkebunan kelapa sawit. Menurut Allorerung et al. dalam Hani (2007), daya saing produk kelapa pada saat ini terletak pada industri hilirnya di mana nilai tambah yang dapat tercipta pada produk hilir jauh lebih besar daripada produk primernya. Salah satu produk hilir kelapa yang berpotensial dan berdaya saing tinggi adalah produk tepung kelapa.

Sulawesi Utara merupakan salah satu provinsi penghasil tepung kelapa di Indonesia. Pada Tabel 1 dapat dlihat bahwa tepung kelapa merupakan salah satu komoditi utama ekspor, karena permintaan tepung kelapa asal Sulawesi Utara masih tinggi dibandingkan provinsi-provinsi penghasil tepung kelapa lainnya serta kualitas tepung kelapa yang sudah terjamin. Setiap tahun, Sulawesi Utara mengekspor hingga ribuan ton tepung kelapa ke berbagai Negara di Eropa maupun Asia, sehingga mampu menghasilkan devisa bagi Negara. Tepung kelapa banyak dibutuhkan oleh industri makanan untuk dipakai sebagai salah satu bahan baku.

Tersedianya bahan baku kelapa yang cukup melimpah di Sulawesi Utara dan potensi tepung kelapa yang semakin diminati pasar internasional, sehingga banyak industri tepung kelapa yang berkembang di Sulawesi Utara.

Permintaan tepung kelapa yang terus meningkat dari berbagai negara, membuat persaingan yang ketat antar perusahaan untuk memenuhi permintaan tersebut dari segi kuantitas serta kualitas produknya. Setiap perusahaan yang ingin mempertahankan eksistensinya dalam persaingan harus menjalankan operasionalnya secara lebih efisien, baik dari sisi biaya, waktu maupun proses. Dalam industri yang memproduksi bahan makanan, konsumen sangat memperhatikan kualitas produk yang dijual. Untuk mempertahankan kualitas tepung kelapa yang diproduksi, maka perusahaan juga perlu memperhatikan mutu dari bahan baku kelapa serta unsur penunjang lainnya, penyimpanan yang higienis dan pengiriman produk kepada konsumen dengan tepat waktu.

Terdapat 9 perusahaan tepung kelapa di Sulawesi Utara dan PT. XYZ merupakan salah satu perusahaan tersebut. PT. XYZ berdiri sejak tahun 1997 dan berkomitmen untuk terus meningkatkan kualitas produk agar dapat bersaing dengan perusahaan tepung kelapa lainnya. Tepung kelapa yang diproduksi oleh perusahaan ini telah diekspor ke berbagai Negara di Eropa maupun Amerika. Dalam mengelola permintaan hingga pengiriman produk, perusahaan menerapkan strategi-strategi tertentu yang harus disesuaikan dengan kondisi internal perusahaan maupun kondisi eksternal perusahaan. Kondisi eksternal yang dimaksud adalah harga bahan baku, mitra-mitra yang bekerja sama dengan perusahaan dan lain sebagainya.

Said et al. (2006) menyatakan bahwa saat ini terjadi perubahan paradigma persaingan. Dari yang semula terjadi persaingan antarperusahaan, menjadi persaingan antar rantai pasok. Rantai pasok merupakan jaringan perusahaan-perusahaan yang saling terintegrasi untuk mendistribusikan produk atau jasa hingga ke konsumen akhir. Perusahaanperusahaan tersebut biasanya termasuk penyedia bahan baku, pabrik, distributor, toko atau ritel, serta perusahaan pendukung seperti perusahaan jasa logistik.

Menurut Indrajit dan Djokopranoto (2002), salah satu faktor kunci untuk mengoptimalkan rantai pasok adalah dengan menciptakan alur informasi yang bergerak secara mudah dan akurat di antara jaringan atau mata rantai tersebut, dan pergerakan barang yang efektif dan efisien yang menghasilkan kepuasan maksimal pada para konsumen.

Selain keterkaitannya dengan jaminan pasar, unsur pendukung di hulu seperti penyediaan bahan baku, sarana produksi dan unsur penunjang lainnya. Satu dari unsur penting keberlanjutan usaha adalah terbangunnya manajemen rantai pasok dari industri tersebut. Manajemen rantai pasok yang dimaksud adalah modifikasi praktek tradisional dari manajemen logistik, yang mementingkan pihakpihak secara individual dan ukan mengacu kepada kinerja keseluruhan ke arah koordinasi dan kemitraan antara pihak-pihak yang terlibat (Budiman, 2013). Sidarto dalam Wibowo (2014) menyatakan bahwa manajemen rantai pasokan merupakan salah satu strategi yang sangat penting dalam menyelesaikan permasalahan perusahaan, mengenai keputusan aktifitas penyedia bahan baku, produsen (perusahaan) dan konsumen. Sehingga suatu sistem produksi yang efektif dan efisien merupakan keharusan yang dimiliki oleh para pelaku bisnis agar dapat memenangkan persaingan.

Tujuan dari penerapan manajemen rantai pasok adalah untuk memastikan agar konsumen mendapat barang (komoditas dan produk) yang tepat jumlah, kualitas dan waktu, serta dengan biaya serendah mungkin. Untuk mencapai tujuan tersebut, manajemen rantai pasok harus mendukung keseluruhan rantai proses mulai dari perencanaan, penyediaan bahan baku, produksi dan distibusinya. Keuntungan manajemen rantai pasok yang efektif adalah untuk mendapatkan kecepatan maksimal pada saat barang dan jasa bergerak melalui jalur rantai pasok, menurunkan biaya, serta meningkatkan nilai tambah bagi pelanggan dan daya saing produk di pasar. 
Tabel 1. Komoditi Utama Ekspor Sulawesi Utara Menurut Volume dan Nilai Ekspor Tahun 2015

\begin{tabular}{lccc}
\hline \multicolumn{1}{c}{ Komoditi } & $\begin{array}{c}\text { Volume } \\
(\mathrm{Kg})\end{array}$ & Nilai & Share $(\%)$ \\
Minyak Kelapa Kasar & $597,925,256.00$ & $555,674,692.83$ & 50.36 \\
Minyak Kelapa Sawit Kasar & $284,243,606.00$ & $161,077,374.17$ & 14.60 \\
Minyak Goreng Sawit & $104,836,217.00$ & $69,506,359.61$ & 6.30 \\
Bungkil Sawit & $205,814,281.00$ & $68,241,608.65$ & 6.19 \\
Minyak Goreng Kelapa & $58,941,145.00$ & $65,362,123.65$ & 5.92 \\
Ikan Kaleng & $15,762,355.75$ & $57,388,906.68$ & 5.20 \\
Ikan Beku & $8,617,041.00$ & $33,064,804.50$ & 3.00 \\
Biji Pala & $2,548,765.00$ & $23,711,649.08$ & 2.15 \\
Tepung Kelapa & $14,439,436.08$ & $22,279,902.27$ & 2.02 \\
Bungkil Kopra & $131,99,399.00$ & $22,094,951.07$ & 2.00 \\
Lain-lain & $12,913,075.25$ & $24,914,124.73$ & 2.26 \\
\hline TOTAL & $1,438,037,577.08$ & $1,103,316,497.24$ & 100 \\
\hline Sumber: Dinas Pering
\end{tabular}

Sumber: Dinas Perindustrian dan Perdagangan Sulawesi Utara (2015)

\section{Perumusan Masalah}

Berdasarkan latar belakang di atas, maka rumusan masalah dari penelitian ini adalah bagaimana PT. XYZ mengelola rantai pasok produknya.

\section{Tujuan Penelitian}

Tujuan dari penelitian ini adalah :

1. Mengidentifikasi model rantai pasok tepung kelapa pada PT. XYZ

2. Menganalisis pengelolaan rantai pasokan tepung kelapa pada PT. XYZ.

\section{Manfaat Penelitian}

Penelitian ini diharapkan berguna bagi perusahaan sebagai bahan masukan dalam penilaian kinerja manajemen rantai pasok, sehingga perusahaan dapat memperbaiki kekurangan dalam mengelola rantai pasok. Penelitian ini juga diharapkan berguna sebagai bahan referensi untuk penelitian-penelitian selanjutnya.

\section{METODOLOGI PENELITIAN}

Waktu danTempat penelitian

Penelitian ini akan dilaksanakan selama 2 bulan yaitu dari bulan September 2016 sampai bulan November 2016 dan berlokasi di PT. XYZ, Sulawesi Utara.

\section{Metode Pengumpulan Data}

Data yang digunakan dalam penelitan ini adalah data primer dan sekunder. Data primer didapat melalui pengamatan langsung di lapangan serta wawancara secara langsung. Wawancara dilakukan dengan pihak perusahaan terkait logistik perusahaan untuk mengetahui gambaran rantai pasok serta pengelolaan rantai pasok yang dilakukan oleh perusahaan. Selain itu, Peneliti juga melakukan wawancara dengan petani kelapa serta pengumpul untuk mengetahui kondisi harga kelapa terkini serta alur bahan baku kelapa dari petani ke supplier. Data sekunder diperoleh dari literatur yang relevan, serta dokumen dan laporan yang dimiliki oleh perusahaan dan instansi terkait.

\section{Konsepsi Pengukuran Variabel}

Penelitian ini berfokus pada pengelolaan aliran material serta aliran informasi dari rantai pasok tepung kelapa pada PT. XYZ. Adapun variabel yang akan digunakan adalah sebagai berikut:

1. Tahap pengelolaan permintaan

Permintaan pelanggan menjadi acuan perusahaan untuk semua kegiatan pada PT. XYZ. Tahap ini juga terkait dengan sistem order yang diterapkan oleh perusahaan.

2. Tahap persediaan bahan baku

- Pemilihan supplier bahan baku

- Pengadaan bahan baku

- Pengiriman bahan baku dari supplier hingga ke perusahaan

- Pengendalian persediaan bahan baku

3. Tahap produksi

- Penjadwalan produksi

- Pemakaian tenaga kerja dan mesin

- Pengolahan produk

- Pengendalian kualitas produk

4. Tahap Distribusi

- Penjadwalan pengiriman

- Pemilihan jasa ekspedisi

- Pengiriman produk

- Memonitor pergerakan produk sampai kepada pelanggan 


\section{Metode analisis data}

Hasil dari observasi dan wawancara dianalisis dengan metode analisis kualitatif deskriptif. Sujarweni (2014) mengemukakan tahap-tahap dalam analisis kualitatif, yaitu (1) reduksi data, (2) penyajian data, (3) penarikan kesimpulan. Analisis deskriptif digunakan untuk memberikan gambaran atau uraian atas suatu keadaan sejelas mungkin tanpa ada perlakuan terhadap obyek yang diteliti (Kountur, 2009). Gambaran model rantai pasok tepung kelapa pada PT. XYZ, mulai dari supplier bahan baku hingga konsumen serta pengelolaan aliran material dan aliran informasi dideskripsikan secara terperinci.

\section{HASIL DAN PEMBAHASAN}

\section{Gambaran Umum Perusahaan}

PT. XYZ merupakan salah satu perusahaan di Sulawesi Utara yang memproduksi tepung kelapa. Perusahaan ini berdiri sejak tahun 1997 dan memiliki 278 karyawan, termasuk pekerja borongan untuk bagian produksi. PT. XYZ terus berkomitmen untuk terus memproduksi dan memasok produk yang berkualitass serta aman untuk dikonsumsi.

\section{Model Rantai Pasok Tepung Kelapa PT. XYZ}

Berdasarkan hasil identifikasi, rantai pasok tepung kelapa yang dikelola oleh PT. XYZ dimulai dari supplier bahan baku, PT. XYZ, jasa ekspedisi, dan pelanggan yang dapat dilihat pada Gambar 1 .

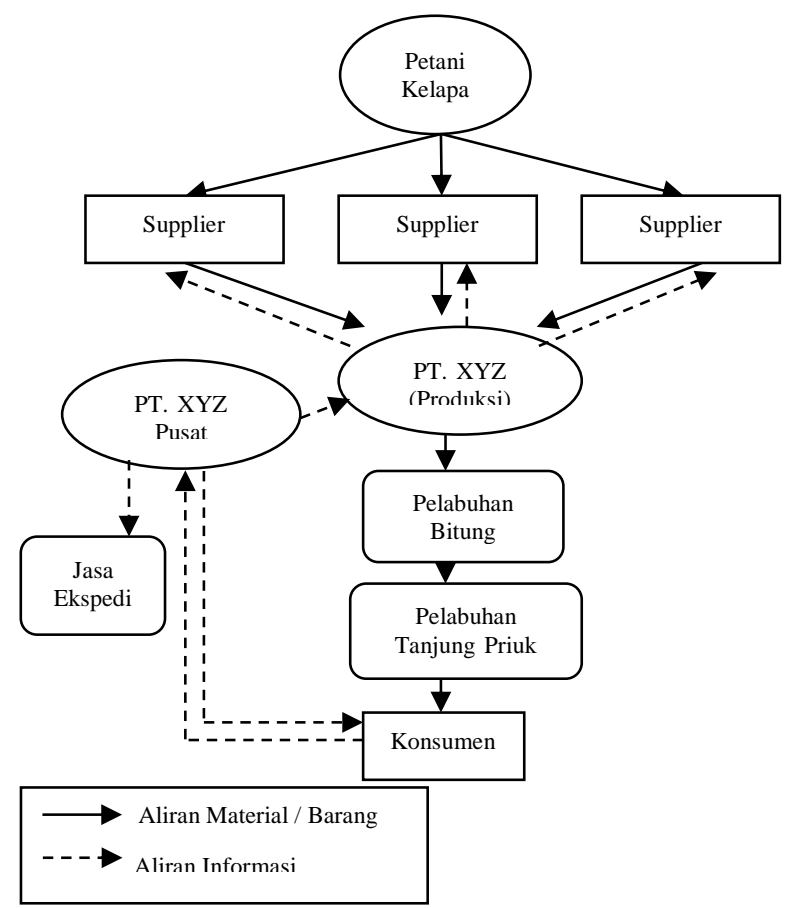

Gambar 1. Model Rantai Pasok Tepung Kelapa PT. XYZ

\section{Supplier}

Supplier membeli kelapa dari beberapa petani kelapa yang berada di sekitar wilayahnya dengan kisaran harga beli Rp. 1.000 - Rp. 1.500. Supplier bahan baku berasal dari daerah Tombatu, Klabat, Dimembe, Kabima, Wori, Kamangta, Jalan Sea, Tara-tara, Sonder, Senduk, Duloduo, Maelang dan Molibago. Bahan baku kelapa dipasok setiap hari dan kuantitas pasokan tergantung pada kemampuan masing-masing pemasok, lalu didistribusikan ke pabrik untuk diproduksi.

\section{PT. XYZ}

PT. XYZ memiliki dua lokasi yang berbeda, kantor pusat PT.XYZ terletak di Manado yang menangani bagian keuangan serta kegiatan pemasaran, pembelian dan pengiriman. Sedangkan pabrik PT. XYZ terletak di Minahasa Selatan yang khusus menangani bagian produksi tepung kelapa. Pelanggan melakukan pemesanan dengan bagian marketing di kantor pusat. Setelah itu bagian marketing memberikan informasi tentang kuantitas dan jenis tepung kelapa yang dipesan, serta waktu pengiriman yang telah disepakati kepada manager pabrik untuk dibuat jadwal produksi.

\section{Jasa Ekspedisi}

Jasa Ekspedisi berperan dalam proses pengiriman produk dari PT. XYZ hingga kepada konsumen. Pengiriman tepung kelapa melalui pelabuhan Bitung dan dilanjutkan ke pelabuhan Tanjung Priuk Jakarta untuk dikirim ke berbagai Negara tujuan ekspor. Jasa ekspedisi juga memberikan informasi tentang pergerakan barang kepada perusahaan serta memastikan barang telah sampai ke konsumen dengan tepat waktu.

\section{Konsumen}

Konsumen merupakan mata rantai terakhir dari rantai pasok tepung kelapa pada PT. XYZ. Konsumen dari PT. XYZ adalah perusahaan-perusahaan yang menggunakan tepung kelapa sebagai salah satu bahan baku untuk kebutuhan produksi. Perusahaan mengekspor tepung kelapa ke perusahaanperusahaan di berbagai negara, seperti Belanda, Belgia, Hongkong, Australia, Selandia Baru, Italia, Amerika Serikat, Korea Selatan, Angola, Jerman, Hungaria, India, Jepang, Malaysia, Polandia, Rusia, Arab Saudi, Afrika Selatan, Singapura, Srilangka, dan Turki.

Beberapa perusahaan sudah lama menjalin kerja sama dengan PT. XYZ dalam memasok kebutuhan tepung kelapa, salah satunya adalah 
perusahaan coklat yang berada di Belanda. Setiap 4 atau 6 bulan sekali, tim yang dibentuk oleh perusahaan cokelat tersebut datang ke PT.XYZ untuk melakukan audit. Tim tersebut melakukan pengecekan khususnya kondisi pabrik untuk produksi tepung kelapa, kebersihan dalam pengolahan produk, penjaminan mutu produk oleh PT. XYZ dan lain sebagainya. Selain perusahaan cokelat yang ada di Belanda, PT. XYZ juga menjalin kerjasama dengan perusahaan yang berada di Australia. Sehingga PT. XYZ dapat melakukan penawaran langsung ke perusahaan tersebut.

\section{Pengelolaan Rantai Pasok oleh PT. XYZ Tahap pengelolaan permintaan}

Perusahaan menganut pull-based system dimana kegiatan produksi maupun distibusi produk didasarkan atas permintaan konsumen, bukan melalui peramalan. Namun, perusahaan tidak selalu menjalankan kegiatan produksi berdasarkan permintaan, karena dalam sekali produksi dapat menghasilkan dua tipe tepung kelapa. Kondisi saat ini, perusahaan harus menyeimbangkan antara jumlah permintaan dengan kapasitas produksi sehingga perusahaan tidak menerima semua permintaan yang ada. Konsumen yang berada di luar negeri biasanya melakukan pemesanan melalui e-mail, dengan cara forward booking. Setelah proses pemesanan selesai, bagian marketing di kantor pusat Manado memberikan informasi kepada manager pabrik tentang jenis tepung yang dipesan, kuantitas yang akan dikirim, dan waktu pengiriman yang telah disepakati.

Dalam hal pembayaran yang dilakukan pelanggan, terdapat 3 cara yaitu (1.) Perusahaan melakukan pengiriman terlebih dahulu, setelah itu pelanggan melakukan pembayaran, (2.) Pelanggan memberikan uang muka terlebih dahulu, setelah produk sampai pelanggan akan melunasi sisa pembayarannya, (3.) Pelanggan dapat melakukan term pembayaran, yaitu pembayaran yang dapat ditunda beberapa lama setelah barang diterima sesuai kesepakatan dengan pihak perusahaan.

\section{Tahap pengadaan bahan baku}

PT. XYZ memasok bahan baku kelapa dari berbagai daerah yang tersebar di Sulawesi Utara, seperti Minahasa Utara, Minahasa Induk dan Bolaang Mongondow. Dalam hal memilih supplier bahan baku, PT. XYZ melakukan wawancara terlebih dahulu untuk mengetahui informasi tentang supplier, seperti keadaan lokasi dan gudang untuk bahan baku, kapasitas kelapa yang dapat dikirim pemasok, serta orang-orang yang dipekerjakan. Pihak perusahaan juga memberikan informasi tentang standar kualitas kelapa yang digunakan untuk produksi, seperti berat standar biji kelapa minimal 8 ons, biji kelapa tidak muda, tidak busuk dan tidak pecah.

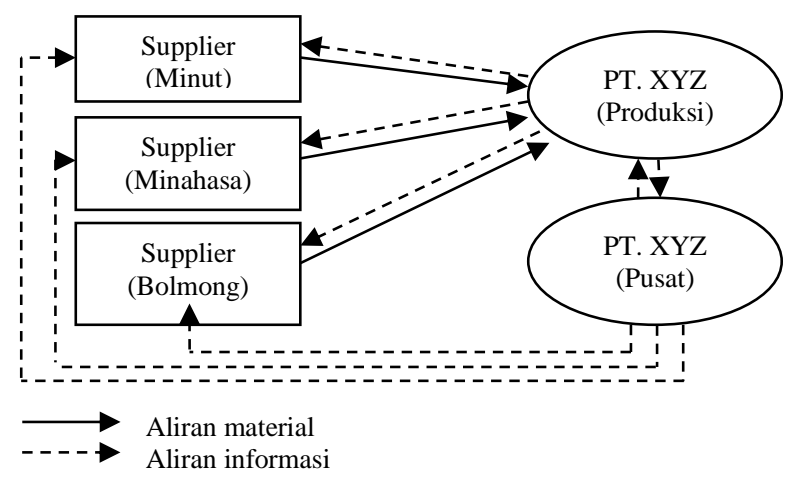

Gambar 2. Aliran Rantai Pasok Dari Supplier ke PT. XYZ (Mata Rantai 1)

Setelah pihak perusahaan dan supplier mencapai bentuk kerjasama yang disepakati bersama dan menandatangani kontrak tertulis, maka supplier dapat memasok kelapa ke pabrik PT. XYZ dan kuantitas kelapa yang dikirim sesuai dengan kemampuan supplier. Jika supplier tidak memasok bahan baku selama 1 tahun, maka supplier tersebut akan dikeluarkan dari daftar dan tidak dapat lagi memasok bahan baku ke pabrik PT. XYZ. Setiap hari, perusahaan melakukan pemesanan bahan baku kepada beberapa supplier yang mempunyai persediaan bahan baku untuk memenuhi kebutuhan produksi tepung kelapa sebesar 70 ton per hari. Supplier yang sudah siap, langsung mengirim bahan baku dari lokasinya ke pabrik menggunakan truk milik perusahaan atau milik supplier, jika ada. Waktu yang diperlukan untuk melakukan pengiriman bahan baku tergantung pada jarak antara lokasi bahan baku dan pabrik. Waktu pengiriman bahan baku dari supplier ke pabrik dapat dilihat pada Tabel 2. Dalam hal ini, terdapat juga supplier yang tidak tepat waktu dalam mengirim bahan baku ke pabrik.

Tabel 2. Waktu Pengiriman Bahan Baku Menurut Daerah Asal

\begin{tabular}{cccc}
\hline Daerah & \multicolumn{3}{c}{ Waktu (jam) } \\
\cline { 2 - 4 } $\begin{array}{c}\text { asal } \\
\text { bahan } \\
\text { baku }\end{array}$ & $\begin{array}{c}\text { Minahasa } \\
\text { Utara }\end{array}$ & Minahasa & $\begin{array}{c}\text { Bolaang } \\
\text { Mongondow }\end{array}$ \\
\hline $\begin{array}{c}\text { Waktu } \\
\text { pengiri } \\
\text { man }\end{array}$ & 8 & 7 & 48 \\
\hline
\end{tabular}

Cat.: Pengangkutan bahan baku menggunakan truk milik perusahaan (Antar-Jemput)

Sumber: Data Lapangan (2016) 
Setiap tahun, perusahaan membentuk beberapa tim dalam rangka mengunjungi setiap supplier untuk menjaga relasi yang baik. Selain itu, kegiatan kunjungan tersebut bertujuan untuk menjelaskan kembali kepada supplier tentang kualitas bahan baku yang diterima perusahaan, meninjau kembali lokasi bahan baku agar jauh dari area pertambangan, gudang penyimpanan kelapa harus bersih dan jauh dari kandang hewan.

Pembelian bahan baku kelapa dilakukan oleh bagian Nuts Buying yang berada di kantor pusat PT. XYZ. Harga pembelian bahan baku kelapa saat ini cenderung naik berkisar antara Rp. 2.250-Rp. 2.300 per kilogram. Naiknya harga beli kelapa disebabkan oleh musim kemarau panjang yang terjadi pada tahun 2015 dan mengakibatkan produktivitas serta kualitas dari kelapa menurun. Selain itu, akibat dari turunnya produktivitas dan kualitas kelapa yang dihasilkan tahun ini, perusahaan harus menunggu 3 sampai 4 hari agar stok bahan baku dapat tercapai untuk memenuhi kebutuhan sebanyak 70 ton. Bahan baku disimpan dalam tempat penyimpanan khusus kelapa sampai stok bahan baku terpenuhi. Persaingan antar perusahaan sejenis juga berpengaruh pada proses pengadaan bahan baku perusahaan.

Sulawesi Utara terdapat 9 perusahaan yang memproduksi tepung kelapa, sehingga satu supplier kelapa tidak hanya memasok bahan baku ke satu perusahaan saja tetapi ke beberapa perusahaan lainnya. Beberapa supplier terkadang memprioritaskan perusahaan yang penawarannya lebih tinggi dari segi kuantitas pemesanan dan harga yang disepakati.

\section{Tahap Produksi (Mata Rantai 2)}

PT. XYZ memproduksi beberapa jenis tepung kelapa yang diklasifikasikan menjadi dua, yaitu granulated dan special cut. Jenis granulated dibedakan lagi menjadi 3 tipe yaitu fine, medium, dan extra fine, sedangkan special cut dibedakan menjadi 2 tipe yaitu chips dan fancy shred. Tipe medium merupakan tipe yang paling banyak dipesan oleh industri makanan dan khusus untuk special cut akan diproduksi jika ada pemesanan.

Seperti pembahasan sebelumnya, saat ini harga pembelian bahan baku cenderung naik serta menurunnya produktivitas dan kualitas kelapa sehingga berimbas pada menurunnya kuantitas pasokan bahan baku yang tersedia di pabrik. Oleh karena itu, sebelum perusahaan menerima pesanan dari beberapa konsumen, perusahaan harus terlebih dulu mengetahui kapasitas produksi real yang dapat dipenuhi oleh perusahaan. Tujuannya agar terjadi keseimbangan antara permintaan dan kapasitas produksi dari pabrik. Kapasitas produksi untuk tahun ini hanya berkisar 60 sampai 70 ton per hari, jika bahan baku kelapa melimpah dapat mencapai 100 ton per hari.

Setelah bahan baku kelapa sampai ke lokasi pabrik, truk beserta isinya akan berhenti pada jalur timbangan untuk ditimbang secara otomatis yang akan menunjukkan berat dantercetak dalam formulir. Selanjutnya, truk menuju tempat penampungan kelapa untuk dibongkar dan disortir mutunya agar mendapatkan kualitas kelapa yang sesuai dengan standar. Kelapa yang pecah dan tidak baik mutunya akan ditempatkan di penampungan khusus untuk dibuat menjadi kopra. Proses produksi tepung kelapa pada PT.XYZ melalui tahap-tahap berikut ini:

a. Setelah kelapa sudah disortir, selanjutnya kelapa-kelapa tersebut akan dihitung secara otomatis dengan mesin nuts counter untuk dimasukkan ke dalam kotak-kotak masingmasing 100 biji kelapa.

b. Pada saat kelapa akan diproses, mula-mula dilakukan pemisahan antara tempurung dengan daging kelapa secara mekanik menggunakan shelling machine oleh pekerja laki-laki (sheller), kemudian buah kelapa tersebut dikupas kulit arinya secara manual menggunakan pisau khusus oleh pekerja wanita (parer).

c. Daging kelapa yang sudah dikupas akan melalui pemeriksaan pertama, setelah itu dilakukan pencucian dan dimasukkan ke dalam storage tank yang selajutnya akan dilakukan pemeriksaan kedua untuk masuk ke proses chlorination.

d. Setelah itu, kelapa akan diperiksa untuk terakhir kalinya dan kemudian kelapa akan masuk ke proses penggilingan (grinding) sesuai tipe yang diinginkan (fine dan medium). Lalu, dilakukan perlakuan secara kimia pada konsentrasi standar untuk pengawetan produk.

e. Kelapa yang sudang digiling akan disterilisasi pada suhu $90^{\circ}$ celcius sampai dengan $100^{\circ}$ celcius. Selajutnya masuk ke dalam proses pengeringan dengan menggunakan mesin pengering (dryer) dan hasilnya adalah tepung kelapa (dessicated coconut).

f. Setelah itu, tepung kelapa dikemas sesuai dengan permintaan pembeli (fine dan medium). Sebelum dimasukkan ke dalam gudang, tepung kelapa yang sudah dikemas harus melalui metal detector untuk memastikan tidak ada kandungan logam di dalamnya. 
Waktu yang dibutuhkan untuk memproduksi tepung kelapa adalah 2 jam. Pihak perusahaan tidak memiliki rincian waktu yang dibutuhkan dari unit produksi ke unit lainnya. PT. XYZ mempekerjakan 278 orang, termasuk pekerja borongan pada bagian shelling dan paring dengan waktu kerja selama 7 jam per hari dan memberlakukan sistem shift untuk bagian produksi.

Tepung kelapa yang sudah dikemas dimasukkan ke dalam gudang, sebelum siap diekspor maka terlebih dahulu sampel tepung kelapa harus melewati proses pengujian di laboratorium milik perusahaan untuk memastikan bahwa produk benar-benar memenuhi persyaratan. Waktu yang dibutuhkan untuk menunggu hasil laboratorium adalah 4 hari. Dalam menjamin mutu produk, perusahaan sudah memiliki beberapa sertifikat salah satunya ISO 22.000:2005 dan setiap 6 bulan ISO tersebut harus terus diaudit agar mutu produk sesuai dengan peraturan yang berlaku. Selain itu, tepung kelapa tidak boleh lebih dari 1 bulan di dalam gudang penyimpanan karena akan mempengaruhi kualitas produk. Setelah hasil laboratorium keluar dan tepung kelapa sudah siap diekspor, maka akan dimuat ke dalam kontainer yang telah disiapkan. Namun, sebelumnya perusahaan harus menunggu hingga 7 hari agar tepung kelapa dapat terpenuhi di dalam 1 kontainer. Sehingga, total waktu yang diperlukan agar tepung kelapa dapat diekspor adalah 11 hari. Tiap minggu, perusahaan mengirim 2 kontainer tepung kelapa dan salah satu tujuannya agar gudang penyimpanan tidak cepat penuh karena jika gudang penyimpanan penuh maka kegiatan produksi dihentikan sementara.

\section{Tahap Distribusi}

Setelah tepung Kelapa dinyatakan siap untuk diekspor, maka manager pabrik akan memberikan informasi kepada bagian marketing dan diteruskan kepada bagian shipping yang berada di kantor pusat untuk ditindak lanjuti. Tepung kelapa akan diangkut menggunakan container untuk dibawa ke pelabuhan Bitung. Seperti di pembahasan sebelumnya, dikatakan bahwa tiap minggu perusahaan melakukan pengiriman 2 sampai 3 kontainer, namun untuk saat ini perusahaan hanya mengirim paling banyak 2 kontainer. Perusahaan dalam menjadwalkan pengiriman menyesuaikan dengan jadwal kapal yang akan berangkat untuk mencegah penumpukan di pelabuhan. Jarak antara pabrik dengan pelabuhan Bitung yang cukup jauh menjadi pertimbangan perusahaan dalam hal mengirim produk. Sehingga perusahaan perlu tahu informasi untuk jadwal keberangkatan kapal secara akurat agar tidak terjadi keterlambatan. Misalnya, closing di pelabuhan Bitung akan dilakukan pada hari Jumat maka perusahaan harus mengantar produk dari pabrik pada hari Rabu atau Kamis yang selanjutnya akan langsung dikirim.

Dalam hal pemilihan jasa ekspedisi, perusahaan tidak mempunyai kriteria maupun kerjasama yang khusus dengan jasa ekspedisi tertentu. Jadi, pada saat akan melakukan pengiriman, perusahaan menggunakan jasa ekspedisi yang sudah siap untuk pengiriman. Setelah perusahaan mendapatkan jasa ekspedisi yang sudah siap dan telah membayar biaya pengirimannya maka produk akan di angkut dari pabrik menggunakan container menuju pelabuhan Bitung. Selanjutnya, produk akan dimuat ke dalam kapal dan dikirim menuju pelabuhan Tanjung Priuk Jakarta untuk diperiksa dan diekspor ke berbagai Negara tujuan. Selain produk, dokumen-dokumen yang diperlukan juga dikirim kepada konsumen seperti invoice, pemberitahuan ekspor barang (PEB), Surat keterangan asal barang, dan sertifikat Phytosanitary. Waktu rata-rata yang dibutuhkan untuk mengirim produk kepada konsumen adalah 2-3 minggu tergantung jaraknya. Perusahaan juga memonitor pergerakan produk untuk memastikan produk sampai ke tangan konsumen dengan tepat waktu. Perusahaan akan menerima laporan dari jasa ekspedisi secara online, seperti informasi produk sudah sampai dimana dan siapa yang menerima produk tersebut.

\section{KESIMPULAN DAN SARAN}

\section{Kesimpulan}

Kesimpulan dari hasil wawancara serta pembahasan penelitian ini adalah:

1. Anggota rantai pasok tepung kelapa pada PT. XYZ, yaitu (a) supplier bahan baku kelapa yang tersebar di beberapa daerah, (b) PT. XYZ untuk bagian pembelian, penjualan, pengiriman dan produksi, (c) Jasa Ekspedisi untuk mengirim produk dari pelabuhan Bitung, selanjutnya ke pelabuhan Tanjung Priuk untuk diekspor ke Negara tujuan, (d) Pelanggan, dalam hal ini perusahaan makanan yang membutuhkan bahan baku tepung kelapa untuk diproduksi menjadi cokelat batang, kue, dessert dan lain sebagainya. 
2. Pemilihan supplier pada PT. XYZ sudah cukup baik, karena setiap supplier yang akan memasok bahan baku harus melalui tahap wawancara, membuat kesepakatan dengan pihak perusahaan dan menyetujui persyaratan yang diajukan oleh perusahaan. PT. XYZ juga menjaga relasi yang baik dengan para suppliernya dengan mengadakan kunjungan setiap tahunnya. Aliran material dan aliran informasi yang dikelola oleh PT. XYZ cukup baik. Setiap informasi pembelian, penjualan, pengiriman dan keuangan berpusat di Kantor pusat PT.XYZ yang berada di Manado dan pabrik PT. XYZ mengelola informasi tentang kuantitas bahan baku yang tersedia di gudang serta kondisi umum pabrik.

\section{Saran \\ Saran yang dapat diberikan melalui penelitian ini adalah: \\ 1. Perusahaan perlu melakukan evaluasi kinerja supplier secara periodik dan menemukan solusi untuk supplier yang tidak konsisten dalam hal prioritas untuk memasok bahan baku ke PT. XYZ agar pihak perusahaan dapat memenuhi kebutuhan bahan bakunya dengan tepat waktu.}

2. Pihak perusahaan dapat menjalin kerjasama dengan jasa ekspedisi yang terpilih untuk jangka panjang, agar informasi tentang jadwal keberangkatan kapal lebih akurat dan informasi tentang pengiriman lainnya lebih lancar.

3. Dalam proses produksi, pihak perusahaan juga perlu melakukan perhitungan waktu yang lebih detail dari unit produksi yang satu ke unit produksi lainnya dan juga koordinasi internal pabrik perlu ditingkatkan agar jalannya proses produksi lebih efisien.

\section{DAFTAR PUSTAKA}

Anatan, L dan Lena, E. 2008. Supply Chain Management: Teori dan Aplikasi. Jakarta: CV. Alfabeta.

Budiman, E. V. 2013. Evaluasi Kinerja Supply Chain Pada UD. Maju Jaya di Desa Tiwoho Kabupaten Minahasa Utara. Jurnal EMBA, Vol. 1, No. 4.

Gerungan, H. P. 2013. Pendekatan Target Costing Sebagai Alat Penilaian Efisiensi Produksi Pada PT. Tropica Cocoprima. Jurnal EMBA, Vol.1, No.13, Hal. 863-870.
Hani. 2007. Analisis Rantai Pasokan Buah Kelapa (Studi Kasus Rantai Pasokan Buah Kelapa di Kotamadya Bogor). Skripsi tidak diterbitkan. Bogor: IPB.

Indrajit E. R. Dan Richardus, D. 2002. Konsep Manajemen Supply Chain: Cara Baru Memandang Mata Rantai Penyediaan Barang. Jakarta: PT. Grasindo.

Kountur, R. 2009. Metode Penelitian: Untuk Penulisan Skripsi dan Tesis. Jakarta: Penerbit PPM.

Lokollo, E. M. 2012. Bunga Rampai: Rantai Pasok Komoditas Pertanian Indonesia. Penerbit: IPB Press. Bogor.

Mardhiyyah, N. 2008. Kinerja Penyampaian Suku Cadang PT. Toyota-Astra dengan Model Supply Chain Operation Reference. Skripsi pada Fakultas Ekonomi dan Manajemen IPB: tidak diterbitkan.

Pujawan, I N. 2005. Supply Chain Management. Penerbit: Guna Widya. Surabaya

Said, A. I. et al. 2006. Produktivitaas dan Efisiensi Dengan Supply Chain Management. Jakarta: Penerbit PPM.

Sujarweni, V. W. 2014. Metodologi Penelitian. Penerbit: Pustaka Baru Press. Yogyakarta.

Tunggal, A. 2010. Global Supply Chain Management. Jakarta: Harvarindo

Walewangko, Y. M. 2013. Manajemen Rantai Pasokan Guna Meningkatkan Efisiensi Distribusi Motor Honda Pada PT. Daya Adicipta Wisesa. Jurnal EMBA, Vol. 1, No. 3, Hal. 1241-1250.

Wibowo, A. 2014. Analisis Kinerja Manajemen Rantai Pasokan Pada KUD Susu Sumber Makmur Ngantang. Skripsi Universitas Muhammadiyah Malang.

Widyarto, A. 2012. Peran Supply Chain Management dalam Sistem Produksi dan Operasi Perusahaan. Jurnal BENEFIT, Vol. 16, No.2, hal. 91-98. Universitas Muhammadiyah,Suramkart 